https://doi.org/10.22364/htqe.2021.78

\title{
DRAWING AS A RESEARCH METHOD IN THE PROCESS OF ART HISTORY STUDIES
}

\author{
Austra Avotina \\ University of Latvia, Latvia
}

\begin{abstract}
Drawing as a research method in the process of art history studies can help to expand and deepen knowledge about several components of the art content: the form, material, structure, technology, individual means, contextual meaning and place. Hand drawing stimulates the imagination, enhances wellbeing, sharpens the mind and trains the hand. It improves visual literacy and increases visual competence. This method acts as a source of discoveries and additional evidence of exclusive values. A historically significant part of the studies was copying, which nowadays has turned into a sea of easily perceptible (external, superficial) appropriations and creates an impression of quality (created by unique primary sources), but which is false and superficial. The aim of this study and the fundamental idea that has also evoked the questions of this research is that drawing is a research method that activates creativity and allows the implementation of successfully original ideas in the process of art history studies. Drawing as research method is significant in all levels of education because using effective independent learning strategies and methods is even more topical for the student than the pupil.

This article analyses 1254 drawings from a cohort of 38 second-year art students in the study of Art History (3 ECTS, no individual persons are involved in the research, nor are the personal data of individuals used). They are evaluated from the perspective of learning outcomes, including six criteria in the evaluation rubric divided into three methodology groups: imagery method of expression, imitation method of expression and discovery learning method. The study applies the qualitative-empirical research method. The results suggest that drawings from important (in art history) and qualitative (through open access collections in virtual space) examples form a link of innovative qualitative benefits from the knowledge phase of short-term memory to the cognitive phase and long-term memory with deep personal motivation.
\end{abstract}

Keywords: art history, copying, drawing, remote learning, visual literacy. 


\section{Introduction}

The aim of this study and the fundamental idea that has also evoked the questions of this research is that drawing is a research method that activates creativity and allows the implementation of successfully original ideas in the process of art history studies. Drawing as a research method is significant in all levels of education because the skill of using effective independent learning strategies and methods is even more topical for the student than the pupil.

Since John Ruskin and Viollet-le-Duc in the $19^{\text {th }}$ century, drawing has been at the foundation of art studies (Ruskin, 2019, Viollet-le-Duc, 2014). Drawing by observing - from nature, from models, and from imagination is an integral part of academic art studies. A different situation appears in the process of teaching art history. The historically established tradition is that it is necessary to describe the artworks in words because the originals of paintings were not accessible to many people. This has created a considerable dissonance between texts and pictures, and it, in turn, the challenge - not losing the essence of art when teaching history. Indeed, the descriptions of artists' biographies have always been significant. Still, nowadays, such sources as descriptions of artists' lives by Giorgio Vasari first published in 1550 or the book by Karel van Mander about the Dutch painters published at the beginning of the 17th century are highly appreciated (Vasari, 1912-14, Mander, 1969). Remarkable stories have been written about the colouring of artworks which was important when colour reproductions were not available, yet the $20^{\text {th }}$-century research on colour theory and colour psychology prove how subjective the perception of colours is. Heinrich Wölfflin's objective classifying principles were equally influential in developing the formal analysis in art history in the early $20^{\text {th }}$ century (Wölfflin, 1991). Many interviews and other written work by art theoreticians and artists, painters are summarised in three volumes covering more than 1000 pages of which the latest one comprises excerpts of the most important texts of the $20^{\text {th }}$ century (Art in Theory, 1900-2000. An Anthology of Changing Ideas, 2002). However, these texts are not particularly suited to improve the hands-on artistic activity. The emerging artists seek visual samples, but this road to the ocean of pictures requires explicit guidance, a roadmap, a guide to these unique values. The process of drawing is one of the ways how to implement this guidance. Therefore, the significant publications for this research should be mentioned. Firstly, Eileen Adams and Jennifer Cromley present evidence of the value of drawing as a medium for learning, as the drawing-to-learn is a specific learning/reading strategy studied across many domains (Adams, 2017, Cromley et al., 2020). Secondly, the 
question about visual literacy. Here the most significant example is the work by Gunther Kress and Theo van Leeuwen, as they talk about changing contexts of text and image in study practice. They are the pioneers of systemic-functional semiotics of the visual culture (Kress \& Leewuen, 2006). And, thirdly, the theoretical framework is supplemented with the practical experiences of Howard Riley and his publications about Drawing as Driver of Creativity (2017, 2019).

The topicality of the research has also been augmented by personal practical experience. Since 2016, three visual literacy weeks have been organised at the University of Latvia in cooperation with the European Network for Visual Literacy, and 24 creative workshops for art teachers have taken place in the framework of these weeks. The principal idea gained from teachers' reflections after the sessions is that visual literacy is rooted in the skills to observe and that drawing (also copying and photography) develops the quality of vision and allows improving the metacognition, which, in turn, can make the planning and monitoring of thinking processes and learning better. Although it is not an innovative discovery, it still proves both the importance of this competency and the evidence to insufficient attention during the teaching/learning process. This idea is also confirmed in the message given by the Common European Framework of Reference for Visual Literacy: visual literacy as a cognitive process is significant for improving different skills - create, present, communicate, use, realise, perceive, analyse, interpret, judge, experiment etc. And vice versa, it promotes human information processing, which is essential for learning; it develops human attention, language, thinking, problem-solving skills, creativity, decision making and others that are relevant in the context of the present research. Drawing (sketching, copying) is essential for the teaching/learning content, and the personally found artefacts activate personal interest and increase motivation, as also expressed in the European prototype. Visual literacy, a competency that is relevant for school subjects such as art, design, or art education, consists of two basic dimensions: producing of- and responding to images/objects (Wagner \& Schönau, 2016). Producing and responding incorporates skills and actions that develop imagination. Visualisation of terms and concepts of art theory relieves their perception and improves stable understanding, but creative experiments with the content and form assign a personally topical value to the studies. It is crucial in the acquisition of art history that it functions convincingly as the creative acquisition of the visual legacy, not the studies of texts ekphrases (a literary description of or commentary on a visual work of art) or long narratives (Rose, 2017) and that the acquisition process engages the highest cognitive processes - problem-solving, judgment, motivation and memory (Škilters, 2019). 
The increase of the importance of ideas and the process in modern art has proved that the most intrinsic justification of creating art (any invention) is the ability (talent) to find an original idea, to notice the problem and to be "obsessed" with it. Contemporary art has demonstrated that the emergence of an original idea is not primarily connected with being able to do, but with thinking; this closely connects with the strategy that we more frequently call design thinking. This has been outstandingly implemented by, for instance, the architect Frank Gehry, who starts the creation process of his new object with free sketching improvisations, for example, Foundation Louis Vuitton (Taylor-Foster, 2014).

The summary of these ideas has found the public space in the documents, the sample programme developed by the Latvian education reform project Skola 2030. These ideas are also expressed in many webinars, embodied in the professional development courses, and since 2020 the introduction of the reform ideas has started in general comprehensive schools of Latvia.

According to the aim of the research performing the quantitative and qualitative analysis of data and interpreting the data with the criteria developed per the concept of visual literacy, it is possible to set the following research questions:

1. Why is it not enough only to listen and look?

2. Does hand-copying develop academic skills? Does it raise the visual (seeing) intelligence?

3. What should be the right mix (related to the target) of the drawing content - from memory, from nature, from a model?

4. What limitations do the digital visual sources set?

\section{Method}

\section{Drawing and remote learning}

It is not a custom to make drawings when studying art history. It used to be a needed practice to ensure remembering an artwork or a picture that was not accessible in any other way. It is unnecessary now because while talking or showing something on the big screen, students have already found it all on their tablets or phones and sometimes even have read something special in parallel. By doing so, they prove that they need direct involvement, personal action. It could be drawing. From experience, as described in the introduction, it is possible to discover that drawing can be good to memorise, to see deeper or notice more. So, in this case, it would be free copying. It is becoming more and more important nowadays, and it is done by almost everyone who is engaged in art studies in general. And digital resources make it possible. Their possibilities are now limitless; 
we can digitally explore details, nuances, fragments that we had no idea about in the pre-digital age. When we wonder about the year 2020 experience with remote learning what this hybrid space "takes away" the answer is it takes away the physical, sensual feeling. We do not feel the object unless we have already seen it in nature (then it is a reminder). But, when working with a foreign object, drawing creates a sense of reality. It creates a new object that is subjectively personalised. Mine. New. Important. Freeform evaluations written by students at the end gave proof of it.

\section{Research design Methodology}

It is essential to note that it is impossible to perform quantitative research in art pedagogy if the aim is to state some socially, aesthetically and emotionally significant manifestations in the teaching/learning process when the core object of study is artworks. In this case, it is utterly important because the research analyses visual data. These are copies of personally significant pictures created by students individually during the remote learning process. A qualitative empirical approach can be considered a well-established strategy for researching in visual art studies (Qualitative researching with Text, Image and Sound, 2000) and representatives of German art pedagogy school Georg Peez (2001) and Ulrike Stutz (2015) have published relevant ideas about this.

The sample of visual data in this research consists of 1254 drawings (no individual persons are involved in the research, nor are the personal data of individuals used) from a single cohort of 38 second-year bachelor art program students (the average age of 20 years) in the study of Art History (3 ECTS). They are evaluated from the perspective of learning outcomes. External features (assessment by observation) including six criteria in the evaluation rubric divided into three methodology groups:

- Discovery Learning Method - to derive concepts, interpret terms, use original principles, add observations, analysis of events and assign personal meaning,

- Imitation Method - repetition - the visual mnemonic that forms the content of a memory mind map,

- Imagery Method - achieve longer focusing - spiritual representation of information in pictures, diagrams (charts) or iconic forms (Tab. 1). 
Table 1. Structure of result analysis

\begin{tabular}{|c|c|c|c|}
\hline Tasks & $\begin{array}{l}\text { Method of } \\
\text { expression }\end{array}$ & Criteria & External features \\
\hline \multirow[t]{2}{*}{ 1. Knowledge } & \multirow{2}{*}{$\begin{array}{l}\text { Discovery } \\
\text { learning } \\
\text { method }\end{array}$} & Thematic & $\begin{array}{l}\text { architecture, sculpture, everyday life, } \\
\text { costumes, portraits, graphic arts }\end{array}$ \\
\hline & & Didactic & $\begin{array}{l}\text { learning, information, explanations, } \\
\text { logic, sequence, irony, comparison }\end{array}$ \\
\hline \multirow[t]{2}{*}{ 2. Skills } & \multirow[t]{2}{*}{$\begin{array}{l}\text { Imitation } \\
\text { method }\end{array}$} & Aesthetically & $\begin{array}{l}\text { masterful, tasteful, careful, beautiful, } \\
\text { ethical, easy to perceive, technically } \\
\text { well executed }\end{array}$ \\
\hline & & Stylistic & $\begin{array}{l}\text { precise copies, the influence of } \\
\text { a unique "handwriting" stylistic unity }\end{array}$ \\
\hline \multirow{2}{*}{$\begin{array}{l}\text { 3. Visual } \\
\text { literacy - } \\
\text { competence }\end{array}$} & \multirow[t]{2}{*}{$\begin{array}{l}\text { Imagery } \\
\text { method }\end{array}$} & Subjectively & $\begin{array}{l}\text { surprising, exciting, emotional, } \\
\text { original, attentive, personal }\end{array}$ \\
\hline & & Wittily & $\begin{array}{l}\text { comments, modern interpretation, } \\
\text { funny, open, personally significant }\end{array}$ \\
\hline
\end{tabular}

The study course Medieval Art History aims to master medieval art of Western Europe, familiarise with the main monuments of medieval architecture and visual art, and analyse artworks created during this period, emphasising the stylistic differences of the key periods of the Middle Ages. Objectives and learning outcomes corresponding to the aim define the choice or the division of the three above mentioned methods:

1. Knowledge and understanding about:

- specific architecture-related terminology, concepts and their explanation;

- development styles of European art history - Romanesque and Gothic art.

2. Skills to analyse, synthesise and evaluate:

- to explore and analyse independently medieval artworks;

- to critically analyse architecture as a type of art and ideological form of expression;

- to use professional terminology and to discover interaction with topical, modern issues.

3. Competence:

- to formulate independently and substantiate with arguments the personal opinion about architecture and visual artworks and their importance;

- to explain the significance of medieval art by providing supporting arguments;

- to purposefully select and independently make a collection of technical drawings to reflect the scope of the recommended content. 
According to the three groups of tasks presented in Table 1, the exact method is selected for each group. Methods, following the principles based on the theory of education science, guide the student sequentially to the competency level, starting with acquiring knowledge, improving skills, and leading to personally significant benefits that acknowledge the competency, or in this case, a concrete level of visual literacy.

Thus, the analysis of visual data (drawings) is carried out applying the strategies of the coding system, the codes being defined by the tasks to be performed and the individual way (scale of criteria) how they are realised.

This empirically collected visual material can be analysed only with means characteristic to the qualitative research method (Peez, 2001). As students freely chose their visual research methods, it is impossible to determine what they first paid their attention to. It is only possible to conclude what dominates in these drawings. When subjectively assessing a visual material, it is necessary to find a maximally feasible coding system; it should stem from the content, aims, objectives, and learning outcomes of the subject (Rose, 2012).

\section{Results}

Therefore, starting the work, first, the means of quantitative cognitive method should be applied that helps to gain the general overview. At first, it was established that 38 students had submitted 1254 works (or collections of drawings), thus 33 works per student on average. This was the recommended amount of work defined in the course requirements. Of 38 students, 16 , or $42.1 \%$, had chosen the traditional A4 format, but 18 students had chosen the A5 format that is $47.4 \%$. Although the difference is not significant, this still is almost a half, which means that not all consider the usual and generally accepted (the traditionally required, the most widely used) A4 format appropriate and a format friendly for the creative expression. The remaining 4 , or $10.5 \%$ of all students, had used untraditional (bigger or smaller formats), which, in this case, is not a significant percentage yet confirms the necessity of freedom in creative expressions.

\section{Discovery learning method}

The next quantitatively established possible result refers to the discovery learning method, enabling students to realise the knowledge acquisition needs. Thus, the first group of learning outcomes - they consolidate knowledge about the specific architecture-related terminology, find out personally significant concepts and get a more accurate notion about the development styles of European art history - Romanesque and Gothic art. The first 
criterion of this group of methods - thematic - applies most directly to this, and using the respective clear codes - architecture, sculpture, everyday life, costumes, portraits, graphic arts (Table 1), we can obtain an accurate account of each individual's interests because every work corresponds to some of the codes; thus all 1252 can be coded.

The interest in everyday life (478) and costumes (237) is dominant. Architecture (214) and sculpture (150) form the next group. The least represented are portraits (95) and graphics (80). Such a proportional division that corresponds to the medieval material itself serves as evidence of both the dominant interest and the willingness to see in the respective visual material of the historical artefacts the link with today, thus forming a friendlier contact with history in their notions (Fig. 1).

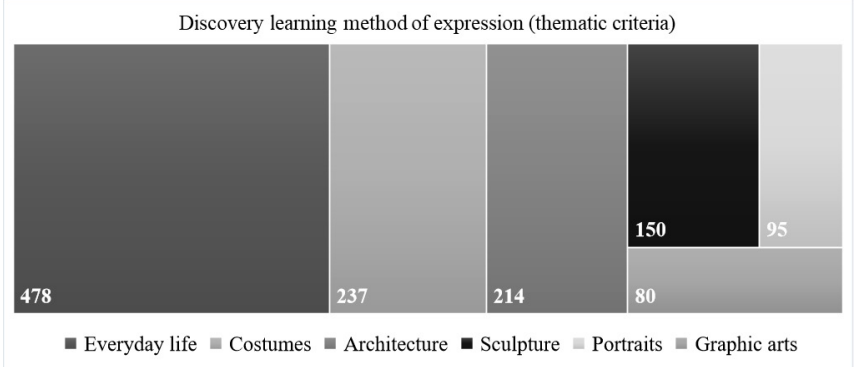

Figure 1. Discovery learning method of expression (thematic criteria)

There is enhanced interest in architecture and sculpture, proving that it is problematic to understand the structures of three-dimensional objects in verbal narratives. These indicators attest to the willingness to explore, learn, and remember precisely voluminous, spatial, and complex objects. The next criterion of the discovery learning method corresponds entirely to memorising. This is the didactic criterion, according to which students with this material of drawn copies implement the knowledge acquisition needs. The respective codes - learning, information, explanations, logic, sequence, irony, comparison - already partially duplicate each other (for example, information and explanation) and form the spectrum attributable to this discovery learning method. While looking through the submitted works, it was possible to state that 800 (63.8\%) works, all in all, concerned the first three codes, and only 250 were such in which sequence, irony or comparison could be noted. The remaining 454 (36.2\%) works were hard to be classified as belonging to this group, which means that students had been creatively or emotionally carried away by interpretations. Those works will be commented upon discussing the third or competence methods. 


\section{Imitation method of expression}

Looking again through all the drawings by the features of the second group of tasks that include the demonstration of skills and, respectively, is the imitation method, it should be concluded the expression of both criteria - aesthetical and stylistic - was found in 689 (54.9\%) works, which could be described as the artistically high-quality evidence of personal taste, talent and skills (Fig. 2). Regarding the context of this category in general, this is a very high indicator and confirms students' skill to explore and analyse independently medieval artworks, to analyse architecture critically as a type of art and ideological form of expression (in 26 works) and to use the professional terminology in their comments. The selection of these works could be performed, applying the codes attributable to the aesthetic criterion - masterful, tasteful, careful, beautiful, ethical, easy to perceive, technically well executed. But the evaluation of the stylistics had equally great importance in the analysis process of drawings. Using such codes as - precise copies, the influence of a unique "handwriting" stylistic unity, the author's skill to form a set of drawings corresponding to common stylistics was established. Many drawings were surprised with the demonstration of precise observation skills, which, exploring artworks visually, is one of the main skills and this was discussed at the beginning of the article. However, as this category is attributable to skills that are an important set of outcomes in the education process, then the respective $54.9 \%$ seem to be too small an indicator. As this group forms the visual, most important learning material, then it leads to the conclusion that stricter tasks with concrete requirements and explanations are needed here. For instance, what should be considered when copying (also interpreting with a definite aim in mind) some artwork. Being the skills-related tasks, they ask for certain artistic skills, a sense of style and accurate work. The concreteness of requirements would have given better results in this group.

\section{Imagery method of expression}

Moving to the third group of tasks makes it conclude that seemingly low indicators of the skills group do not significantly affect the final outcome as it could be anticipated. It allows concluding that both the codes of the first and second criterion should be changed for the skills or imitation method group.

The third group of tasks that corresponds to the imagery method has two criteria - subjectively and wittily. They are attributable to the group of tasks in which there dominate independently formulated and well-argued (visually or textually) opinions about the works of architecture and visual art. Purposefully chosen and independently formed, sometimes 
very original (11 authors of 38 , or $31.6 \%$ ) collections of drawings that reflected both students' understanding and specific (at times, surprising) skills and imagination that purposefully demonstrated the scope of the reviewed content, were established here. To formulate the results of this group, the following codes were used - surprising, exciting, emotional, original, attentive, personal, comments, modern interpretation, funny, open, personally significant. All in all, 967 works corresponded to these codes. Although by the criteria and codes, it seems that here the greatest subjectivity is possible, yet the totality of works leads to concluding the opposite. Freedom, creative expression, imagination, and humour are very principal ways of implementing the teaching/learning process; they open a new world, make it personally meaningful, and give life to studying the art history course (Fig. 2).

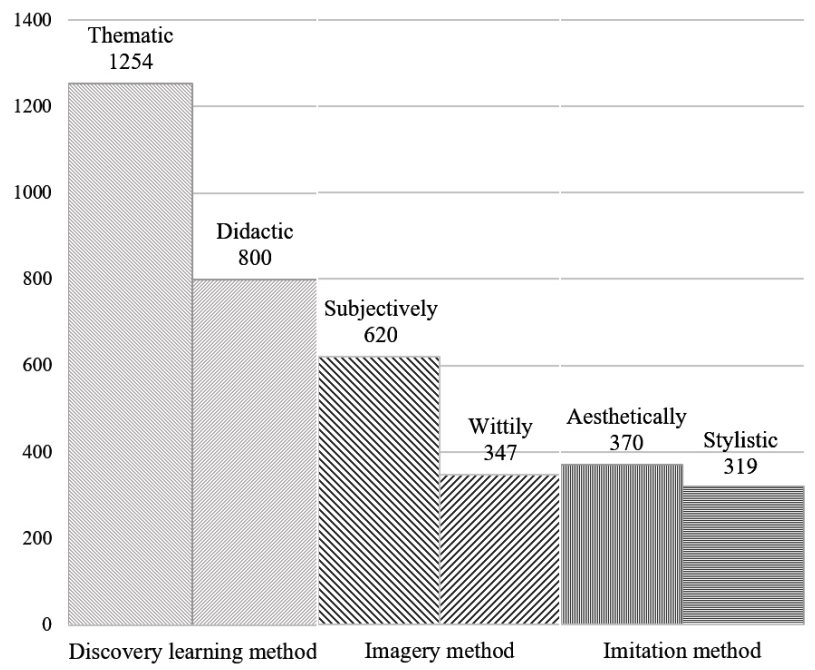

Figure 2. Comparison of all three methods of expression

The totality of these works proved that $77.1 \%$ of students had reached the level of competency and visual literacy that corresponds to the aims of the study course. Students have got acquainted with the principal medieval architecture and artworks and can analyse them visually. It should be mentioned that many works correspond to at least two methods and several criteria. The overlapping of different expression methods that in each group constitutes approximately one-third of works, corresponds to the above mentioned $77.1 \%$. The most important is the set of works in which the manifestation of all three expression methods can be observed. It is well presented in Fig. 3. 


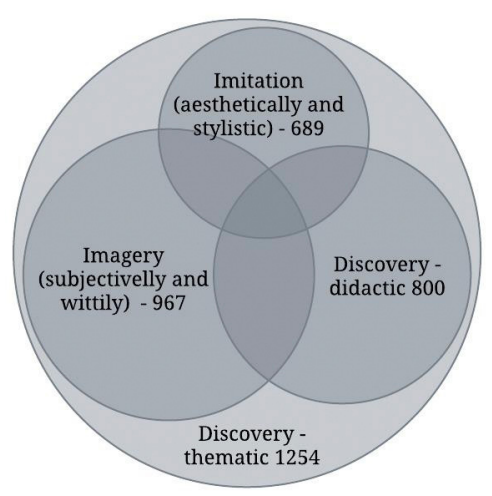

Figure 3. Overlapping of the three methods of expression (a total of 1254)

The darker section in the centre corresponds to $6 \%$ of all works, which means that it is challenging to create drawings that correspond to all possible criteria. As stated, the imagery method and its related criteria form the most significant part of works and, accordingly, prove that students willingly use their imagination; they are somewhat subjective, critical and wish to be witty. It is not possible to demonstrate this in traditional art history studies and forms of testing.

Freeform evaluations written by students confirm that they are motivated and interested in using such teaching/learning methods also in future, even without having it as a task. The importance of the method in the teaching/ learning process and students' personal gain was attested by words that dominated in their texts, such as art (48 times), very (47 times), drawing (37 times), picture (22 times), interesting (22 times), helps (16 times), understanding (12 times), memory (11 times), explore (10 times), creative ( 8 times), liked ( 8 times), knowledge (8 times), teaching/learning (7 times), to think (7 times), acquisition (6 times), awareness (6 times) and excellent (5 times). The overall benefit, in general, can be described quoting a student's words who agreed that his words are published without a name: For me, the most important in the study process is exactly the visual materials because not always years and names stick to my memory. A picture that I have explored in depth or even better, copied, stays in my memory for life. Besides, the association also with the year and name is formed that together with the drawing remain in my memory.

\section{Discussion}

Several traditionally accepted statements of the pedagogical methodology for the so-called theoretical courses should be revised as the result of the research. The proportion of the verbal, presenting, and practical 
classes should be changed because the real benefit from practical actions is assessed insufficiently in the education process. Due to restrictions caused by the pandemic, seeking new teaching/learning forms and methods, a way how to motivate students for learning, how to evoke interest about the content of the study course and assign it personal importance was revealed. However, this experiment only opened up a group of questions for the discussion to answer the following:

1) do learning tasks (formulation of results and assessment criteria) provide an opportunity for:

- creative expression,

- gaining experience,

- developing curiosity,

- use of imagination.

2) do learning tasks (course content and independent work) provide an opportunity for:

- problem-solving,

- identifying oneself,

- innovative discoveries.

The actualisation of these questions in a broader time dimension would also change the attitude to the theoretical courses in the process of art studies where, until the present, strictly separating them, a general notion about the heterogeneous subordination of theory and practice, and their importance in the study process is being formed.

\section{Conclusions}

Answering the first research question - Why is it not enough only to listen and look? The content of art history, in distinction from other theoretical subjects, offers unique visual material that is the core content. Practical action requires careful investigation that can be complete only precisely copying what is seen or the original drawing, or measurement in nature, or the scrutiny of pictures enlarging them digitally and accurately copying should be applied in studying it.

Indeed, art bachelor students can draw, but during the first introductory lesson without using any visual samples, invited to draw by heart, from memory what came to their mind thinking about the Middle Ages, almost all drawings were similar, relatively a low level of academic quality. These drawings were naturally naive, primitive and resembled those that could be drawn by anyone. At the end of the term, the quality of the submitted collections of drawings (virtuosity of the hand in the drawing, precision, linear accuracy) was very high, which serves as evidence that hand-copying develops academic skills. From this point of view, it raises the visual 
(seeing) intelligence because the comments added to many works mentioned exactly the surprise about what students had noticed during the copying, about what they had not thought about at all before the exploring.

Answering the third question - what should be the right mix, related to the target, of the drawing content - from memory, from nature, from a model, it is possible to prove that equal proportional relation between drawings from memory, from nature and from a model is the ideal version. This proportion was observed in the collections of works of those $11(31.6 \%)$ students that received the highest assessment. These were purposefully chosen and independently developed thematically, at times, very original collections of drawings that reflected both students' comprehension and specific (at times, surprising) skills and the imagination purposefully demonstrated the scope of acquiring the reviewed content. This is the evidence that interest and engagement with this task were evenly maintained during the term because every impulse (from memory, from nature, from a model) was linked to some of the ideas of medieval art or interpreted it.

Digital visual sources are of great importance in the acquisition process of art history; its significance can be compared to examining the original. Looking at the original painting in the museum, the costume in the display-case, the building in nature, there are often some natural limitations (distance, light, size, vantage point, peculiarities of the surface) that do not allow exploring the work in full. Therefore, the digital environment has brought unique possibilities in this study course. They should be acknowledged and used. One of the virtual space challenges is the seeming hurry with which we use it in our everyday life. The copying task prolongs the time needed for examining, encourages delving into and gives a possibility to see specific features which then (often during the whole life) are searched for as already known, they are easier found in the surrounding environment and always allow remembering what has been acquired in the study course as a personally significant value.

So, it is possible to conclude that drawing is a way of thinking that activates creativity and allows the implementation successfully original ideas in the results of the study process.

\section{References}

Adams, E. (2017) Thinking Drawing. International Journal of Art \& Design Education, 36(3), 244-252.

Art in Theory, 1900-2000. An Anthology of Changing Ideas (2002). Ch. Harrison \& P. Wood (Eds.). Blackwell Publishing.

Cromley, J., Yang Du \& Dane, A. P. (2020) Drawing-to-Learn: Does Meta-Analysis Show Differences between Technology-Based Drawing and Paper-and-Pencil Drawing? Journal of Science Education and Technology, 29(2), 216-229. 
Kress, G., Leewuen, J. van (2006) Reading Images. The Grammar of Visual Design (2 ${ }^{\text {nd }}$ Ed.) Routledge.

Mander, K. van (1969) Het schilder-boeck. [The Painter's Book]. Retrieved from: https:// www.dbnl.org/tekst/mand001schi01_01/mand001schi01_01_0001.php

Peez, G. (2001) Qualitative empirische Forschung in der Kunstpädagogik. Books on Demand. Qualitative researching with Text, Image and Sound (2000). Sage Publications Ltd.

Riley, H. (2017) Drawing as Driver of Creativity: Nurturing an Intelligence of Seeing in Art Students. The International Journal for Art \& Design Education, 36(3), 273-280. https://doi.org/10.1111/jade.12157

Riley, H. (2019) Drawing as language: the systemic-functional semiotic argument. Journal of Visual Art Practice, 18(2), 132-144. https://doi.org/10.1080/14702029.201 8.1537640

Rose, G. (2012). Visual Methodologies. An Introduction to Researching with Visual Materials. Sage Publications Ltd.

Rose, S. (2017) The Significance of Form. Nonsite. 20. Retrieved from: https://nonsite. org/feature/the-significance-of-form

Ruskin, J. (2019) The Elements of Drawing. Wentworth Press.

Šḳilters, J. (2019). Vizuālā uztvere, uzmanība ceḷā no sajūtām uz pieredzi un zināšanām. [Visual Perception, Attention on the Way from Feelings to Experience and Knowledge]. In A. Avotina (Eds.), Vizuālizpratne kā 21. gadsimta kompetence [Visual Literacy as a $21^{\text {st }}$ Century Competence] (53-60). Latvijas Universitāte.

Stutz, U. (2015) For a Sociospatial Practice of Art Education. Art Education in Germany (pp. 57-62). Waxmann.

Taylor-Foster, J. (2014) Gehry's Fondation Louis Vuitton in Paris: The Critics Respond. ArchDaily. Retrieved from: https://www.archdaily.com/559473/gehry-s-fondation-louisvuitton-in-paris-the-critics-respond?ad_mediu $M=$ gallery

Vasari, G. (1912-14) The Lives of the Most Excellent Painters, Sculptors, and Architects. Macmillan and Co.LD\&The Medici Society, LD. Project Gutenberg. Retrieved from: https://www.gutenberg.org/ebooks/search/?query = vasari\&submit_search $=$ Go $\% 21$

Viollet-le-Duc, E.-E. (2018) Histoire D'un Dessinateur: Comment On Apprend À Dessiner. [Story of a Designer: How We Learn to Draw]. Wentworth Press.

Wagner, E., Schönau, D. (2016) Common European Framework of Reference for Visual Literacy - Prototype. Waxmann.

Wölfflin, H. (1991) Kunstgeschichtliche Grundbegriffe: Das Problem der Stilentwicklung in der neueren Kunst. [Principles of Art History: The Problem of the Development of Style in Later Art]. Schwabe. 